IZA DP No. 5914

Intergenerational Wealth Mobility in Rural Bangladesh

M. Niaz Asadullah

August 2011

Forschungsinstitut zur Zukunft der Arbeit Institute for the Study of Labor 


\title{
Intergenerational Wealth Mobility in Rural Bangladesh
}

\author{
M. Niaz Asadullah \\ University of Reading, \\ SKOPE, University of Oxford and IZA
}

Discussion Paper No. 5914

August 2011

\author{
IZA \\ P.O. Box 7240 \\ 53072 Bonn \\ Germany \\ Phone: +49-228-3894-0 \\ Fax: +49-228-3894-180 \\ E-mail: iza@iza.org
}

Any opinions expressed here are those of the author(s) and not those of IZA. Research published in this series may include views on policy, but the institute itself takes no institutional policy positions.

The Institute for the Study of Labor (IZA) in Bonn is a local and virtual international research center and a place of communication between science, politics and business. IZA is an independent nonprofit organization supported by Deutsche Post Foundation. The center is associated with the University of Bonn and offers a stimulating research environment through its international network, workshops and conferences, data service, project support, research visits and doctoral program. IZA engages in (i) original and internationally competitive research in all fields of labor economics, (ii) development of policy concepts, and (iii) dissemination of research results and concepts to the interested public.

IZA Discussion Papers often represent preliminary work and are circulated to encourage discussion. Citation of such a paper should account for its provisional character. A revised version may be available directly from the author. 
IZA Discussion Paper No. 5914

August 2011

\section{ABSTRACT \\ Intergenerational Wealth Mobility in Rural Bangladesh ${ }^{*}$}

Unique residential history data with retrospective information on parental assets are used to study household wealth mobility in 141 villages in rural Bangladesh. Regression estimates of father-son correlations and analyses of intergenerational transition matrices show substantial persistence in wealth even when we correct for measurement errors in parental wealth. We do not find wealth mobility to be higher between periods of a person's life than between generations. We find that the process of household division plays an important role: sons who splinter off from the father's household experience greater (albeit downward) mobility in wealth. Despite significant occupational mobility across generations, its contribution to wealth mobility, net of human capital attainment of individuals, appears insignificant. Low wealth mobility in our data is primarily explained by intergenerational persistence in educational attainment.

JEL Classification: D63, O53

Keywords: intergenerational inequality, household wealth, occupational mobility, schooling mobility, transition matrix, Bangladesh

Corresponding author:

M. Niaz Asadullah

School of Economics

University of Reading

PO Box 218

Whiteknights

Reading, RG6 6AA

United Kingdom

E-mail: m.asadullah@reading.ac.uk

\footnotetext{
* I am grateful to Professor Stefan Dercon for valuable comments and suggestions. I am also grateful to ICDDR,B for granting me access to Demographic Surveillance System (DSS) data on Matlab thana used in the paper. An earlier version of the paper was presented at Oxford University (CSAE), Reading University, the Open University (UK), Bangladesh Institute of Development Studies (BIDS) and PEGNet workshop on "Poverty reduction, equity, and growth: New issues and findings" at The Kiel Institute for the World Economy (April 2006) and the Royal Economic Society Conference (2006, University of Nottingham). The usual disclaimers apply.
} 


\section{$1 \quad$ Introduction}

Prevalence of income poverty is a hallmark of countries at the bottom of the development discourse. A significant part of the observed income inequality often reflects persistent differences in the capacity of individuals to exploit market opportunities. Economic immobility - persistence in economic status - then reflects inequality of opportunities and therefore the process that underlies persistence in income poverty. As such, two countries with an identical distribution of income in a given year can offer a very different set of economic opportunities to their populations and consequently differ in their capability to minimize income inequality over time and across generations. Therefore, in addition to growth in income and its distribution, knowledge of the extent of relative social mobility is useful in that it provides information about the long-run distribution of outcomes and the factors underlying them.

Despite the policy relevance of research on economic mobility, relatively less is known on the issue for developing countries. A handful of studies nevertheless exist on intra-generational (i.e. inter-temporal) mobility in rural economies of Asia using household level panel data. For example, Swaminathan (1991) uses such data from a South Indian village for the years 1977 and 1985 to examine mobility in wealth. Similarly, Fuwa (1999) uses data from the Philippines to study occupational mobility. In a much-publicised study of a north Indian village, Drèze et al. (1998) examine income mobility over five decades. However, study on persistence in outcomes across generations of the same family is rare.

A key reason for the absence of research on intergenerational mobility in developing countries is a lack of panel data or cross-section data with information on parents. Recently a number of studies have exploited the latter to study persistence in 
economic outcomes across generations. A recent and comprehensive study is by Grawe (2004) who studies father-son earnings data from the US, the UK, Pakistan, Peru, Nepal, Malaysia and Ecuador. Grawe reports substantial earnings immobility in developing countries ${ }^{1}$. Most importantly, when compared to developed countries, mobility is found to be less in developing societies.

This paper provides a microeconometric analysis of Bangladesh's intergenerational wealth mobility, for 141 villages, focusing on male headed households across time and generations. The aim of the paper is to investigate mobility, through a detailed description of the dynamics of socio economic mobility in a developing country. More specifically, it aims to investigate changes in the relative economic and social positions of individuals in rural Bangladesh, over three decades. The analysis is based on cross-sectional data with retrospective records on parental/household characteristics and asset portfolio.

Our analysis suggests limited intergenerational wealth mobility in rural Bangladesh. This is true even when we correct for measurement errors in parental wealth and endogeneity of number of correlates of son's wealth namely, son's family size and whether the son's household is a split-off. Regression analysis of intergenerational wealth data yields an estimate of father-son correlation in the range of 0.53 and 0.77 . Intergenerational persistence is also very high in educational attainment. Examination of various potential economic and demographic correlates of son's wealth shows that education is the most important driver of wealth mobility in rural Bangladesh. A comparison of father-son schooling correlations for different cohorts reveals that schooling mobility has not increased much in rural Bangladesh. This in turn explains the lack of wealth mobility in our data. Nonetheless, our results

\footnotetext{
${ }^{1}$ Fields (2000) discusses additional studies that use panel data from Peru and Malaysia to assess mobility in earnings in developing societies.
} 
should be interpreted with caution. The dataset used in this paper is based on multiple census rounds carried out in Matlab Thana and provide information on all adult sons who resided in the study area between 1974 and 1996. But any son who moved out of the Matlab area from the father's generation is excluded. Such dwelling based sampling implies that our study of economic mobility may suffer from bias to the extent spatial mobility and socio-economic mobility are linked ${ }^{2}$.

The balance of the paper is as follows. Section 2 describes the study area - the Matlab villages - with reference to various aspects of the structural change that has transformed the Matlab area in the last three decades. This helps in explaining the societal context in which we study mobility. The empirical strategy is set out in section 3. It is then followed by a description of the data in section 4 . Results are discussed in section 5 while section 6 concludes.

\section{Social and economic background of Matlab, 1974-1996}

The Matlab thana comprises of 141 villages and is located in Chandpur district, 55 kilometres south-east of Dhaka, the capital of Bangladesh. The economy of Matlab is primarily agricultural, with the majority of population engaged in various farm activities. Average travel time between the Matlab thana and Dhaka is five hours -the villages remain considerably remote chiefly due to poor transport facilities. Villagers therefore significantly rely on the local economy for their daily livelihood (Razzaque and Streatfield, 2001).

The period of 1974-1996 has seen notable socio-economic changes in Bangladesh which is also reflected in the data on the Matlab villages. By virtue of a comprehensive demographic surveillance system (DSS) maintained in the area since

\footnotetext{
${ }^{2}$ Nonetheless, existing international evidence on endogenous attrition in panel studies is mixed. Using Indonesian household survey data, Thomas, Frankenberg, and Smith (2001) find that attritors who move long distances differ statistically from those they leave behind. But in their tests on longitudinal household data from Bolivia, Kenya, and South Africa, Alderman et al. (2001) find little bias in practice.
} 
1966 by the International Centre for Diarrhoeal Disease Research, Bangladesh (ICDDR,B), it is possible to track some of these changes. The extent of poverty and the exact changes in the standard of living over the years in the study area is difficult to ascertain in the absence of income/consumption data. Information on basic assets owned by the households, quality of housing, access to safe drinking water, and sanitation nevertheless exist in the DSS records. Three complete censuses conducted by ICDDR,B yield these data for the years 1974, 1982 and 1996. Substantial growth is observed in the ownership of productive assets and consumer durables in the region between 1974 and 1996. The precise mechanism underlying the changes in living conditions, as measured in terms of basic (non-land) indicators of household wealth, are not clear. "Gains" in living standard are apparently mirrored by a drop in illiteracy rate, a decline in fertility and changing occupational class structure. In 1974, only $33 \%$ of the population in Matlab had some formal schooling. A secular increase in school participation is nevertheless apparent since then - by 1996, ever-schooled population increased to $60 \%$.

The past two decades have also seen a steep decline in the fertility rate in Bangladesh. Noteworthy changes have also occurred in the sectoral composition of the labour force. The share of wage work (agricultural, non-agricultural and service related) declined from $35.7 \%$ in 1974 to $26.6 \%$ by 1996 . This is primarily driven by a reduction in the share of the agricultural labour from $18 \%$ of the workforce in 1974 to $5.1 \%$ by 1996 . The share of waged work in non-farm sector also increased from $17.7 \%$ to $21.5 \%$ in 1996.

The above changes have important implications for economic mobility in the Matlab villages. In this study, we do not exhaustively account for all the determinants of mobility. Neither are we able to test for causal effects of all the determinants. 
Instead, we attempt to describe the extent and nature of generational mobility in schooling and in turn examine how this relates to mobility in wealth.

\section{$3 \quad$ Empirical strategy}

Most of the existing empirical studies on intergenerational economic mobility employ the model of regression to the mean to relate son's status to that of his father. Therefore, we first estimate the following regression:

Son's wealth $=\beta_{0}+\beta_{1}(\text { Father's wealth })_{t}+v_{t}$ (1)

where $v_{t}$ is a random error term. The regression framework focuses on mean mobility where $\beta_{1}$ is the OLS estimate of the degree of generational persistence in wealth. However, equation (1) does not say anything about the drivers of persistence in wealth.

For various reasons, one would expect an intergenerational link in economic status, defined in terms of earnings or wealth. Human capital (e.g. schooling) investment in children combined with the model of intergenerational transmission of innate ability provides a framework to understand such a link (Grawe and Mulligan, 2002). If higher education raises earnings and improves one's wealth status, children of credit-constrained families, those usually with little parental wealth stay relatively poor as a consequence of low education. Wealthy parents may also have a higher taste for education and raise children's schooling independent of credit constraints. Persistence in wealth, therefore, mirrors persistence in schooling. Demography also plays an important role in the process of wealth transmission. A primary channel for acquisition of land - the most valuable productive asset in rural areas - is largely demographic and works through family division. For Indian data, Walker and Ryan (1990) find that $60 \%$ of households subdivided some land intergenerationally and $95 \%$ of the multiple-heir households split and subdivided some land at inheritance. 
Altogether, this process of household partition accounts for most of the decline in average household landholding and consequently, a more important determinant of household wealth compared to household-specific accumulation (Foster and Rosenzweig, 2001). This process, which leads to greater intergenerational persistence among sons who directly inherit a household from the patriarch, a priori predicts downward mobility for split-offs ${ }^{3}$.

To account for the various determinants of mobility, we adopt a step-wise procedure and report additional regressions of son's wealth incrementally controlling for the following covariates: age and age-squared, education, family size, inheritance of (household) headship and occupation. This then yields an alternative estimate of persistence, $\alpha_{1}$, from equation (2). This strategy allows us to track changes in the coefficient on father's wealth following inclusion of each of the additional determinants of son's wealth:

$$
\begin{aligned}
& \text { Son's wealth } \mathrm{t}_{\mathrm{t}} \alpha_{0}+\alpha_{1}(\text { Father's Wealth })_{\mathrm{t}}+\alpha_{2} \text { Age }_{\mathrm{t}}+\alpha_{3} \text { Education }_{\mathrm{t}}+ \\
& \left.\alpha_{4}(\text { Headship Inheritance })_{\mathrm{t}}+\alpha_{5} \text { (Occupation }\right)_{\mathrm{t}}+\alpha_{6}(\text { Family size })_{\mathrm{t}}+\varepsilon_{\mathrm{t}}
\end{aligned}
$$

The OLS estimate of persistence is not robust to the possibility that father's wealth could be measured with error so that estimate of persistence is smaller ${ }^{4}$. Therefore, we also report instrumental variable (IV) estimates of wealth persistence where father's wealth is instrumented by the father's education and occupation ${ }^{5}$.

\footnotetext{
${ }^{3}$ However, the full effect of household formation and dissolution on mobility is unknown. There is a small literature that looks at welfare of individuals in split-offs vs. intact households (Foster and Rosenzweig, 2001). The findings suggest limited welfare gains for the split-offs.

${ }^{4}$ There are very few studies on wealth persistence that tests for such a bias. However, the evidence of a downward bias is evident from the literature on earnings mobility. A series of revisionist studies (e.g. Solon, 1992) report a larger estimate of persistence in the range of 0.4 to 0.6 (compared to older estimates of 0.2), once measurement errors in earnings are accounted for (Solon, 2002).

${ }^{5}$ Charles and Hurst (2003) instrument father's wealth by father's education. Similar 2SLS framework is used in Dunn (2003). In earnings regressions for sons, Dunn instruments father's earnings by father's occupation. Nonetheless, the exogeneity of such instruments is not a priori conspicuous. For example, father's wealth could additionally suffer from the problem of endogeneity if unobserved earnings endowment (such as innate ability) is contained in the error term in equation (2).
} 
A problem also arises with the son's family size, which is often co-determined with his wealth and hence endogenous. Wealthier households, particularly those engaged in farm work, are likely to demand more children in particular if the labour market is imperfect. Thus, we additionally instrument family size by (i) the sex of first (eldest) child and (ii) whether the household is located in the treatment area ${ }^{6}$. Individuals in the treatment villages had access to specialized family planning services offered by the ICDDR,B. Since villages were randomly chosen for this intervention, location in the treatment area is a priori exogenous to household characteristics. Availability of multiple instruments means that our IV models are always over-identified. We therefore carry out conventional tests for the validity of our instruments.

A key feature of our data is that we are able to determine whether a son's household is a split-off or directly inherited from his father. This allows us to investigate another potential cause of mobility in rural areas i.e. household partition. Once again, household division could be driven by resource scarcity or a lack of surplus in one's household of origin (i.e. father's household). If father's wealth is measured with errors, exogeneity of household inheritance status would be of suspect: inheritance status (for sons) could partly capture the effect of unaccounted paternal wealth. We test for this possibility by additionally instrumenting son's inheritance of headship. As excluded instruments, we use two retrospective measures of "within household inequality": birth order of the son and difference in the educational attainments among his siblings. Within household inequalities in human capital (and age) implies that there is a reduced benefit of joint residence and consequently, an

${ }^{6}$ See Angrist and Evans (1998) for an application of similar instruments based on family composition. 
increased probability of household partition (Foster and Rosenzweig, 2001; Rosenzweig, 2003).

It should be noted that regression estimates of father-son correlations do not measure mobility as a positional change in one's wealth distribution. In certain circumstances, instead of mean or level persistence, one may be interested in the rank mobility. The transition matrix approach is superior in this respect. In an intergenerational context, the matrix yields the probability of sons reaching a particular status for a given status of their fathers. The technique works by converting continuous status variables for fathers and sons into discrete ordered variables having same number of ordered categories. Members of each generations/periods are classified according to fixed categories such as equal-sized quantiles, with baseperiod quantile determining the row and destination-period quantile the column. The joint distribution is then parameterized by a $(\mathrm{n} \times \mathrm{n})$ matrix $\mathrm{M}$ containing the transition probabilities. If economic status persists fully across generations/periods, $\mathrm{M}$ would be an identity matrix with all entries lying on the diagonal axis.

A problem with the transition matrix analysis is that it is compounded by lifecycle effects. To this end, we use age-adjusted data instead, using residuals from a regression of wealth on individual's age and age-squared. In addition, we report additional transition matrices using residuals from regressions of son's wealth on the following sets of covariates: (i) age, age-squared, and education (ii) age, age-squared, education and family size and, (iii) age, age-squared, education, family size and occupation respectively ${ }^{7}$. A comparative analysis of these transition matrices provides a crude way to understand the factors that cause father-son mobility in the data.

\footnotetext{
7 To guard against possible outliers, we also repeat the analysis using residuals from median regressions.
} 
Given that the transition matrix approach is purely descriptive, it's difficult to compare mobility between two samples without some overall summary statistics or scalar measures. Therefore, for each transition matrix, M, we compute statistics which give a measure of mobility in terms of time dependence. These are Pearson's chisquare and likelihood-ratio chi-square statistics. These statistics compare expected frequencies (when there is perfect mobility) with observed frequencies and therefore assume larger values the further we are from the state of perfect mobility. For the sake of brevity, however, we only report likelihood-ratio chi-square statistic.

The above two indices, while useful for ranking transition matrices, do not say anything about positional movements: An individual is said to have experienced mobility if she changes position in the status distribution. Hence, for each transition matrix, we also construct an additional total of five indices of mobility: Shorrocks' MET (also known as the Prais index), Atkinson et al. mobility ratio, determinant index, average jump and normalised average jump.

These five mobility indices can be classified as (a) individual cell-related and (b) aggregate measures (Swaminathan, 1991). Both average absolute jump and normalised average jump are of the first type. The rest - Prais index, Atkinson et al. mobility ratio and the determinant index - are aggregate measures of mobility. The Prais index is defined as: $[\mathbf{n}-$ trace of $\mathbf{M}] /[\mathbf{n}-1]$ where, $M$ is the transition matrix and $\mathrm{n}$ is the number of rows/columns. Atkinson (im)mobility ratio focuses on the fraction of cases lying along the principal diagonal and the adjacent cells. By focusing on the diagonal elements, these two measures provide a way to quantify the extent of immobility ${ }^{8}$. They vary with (i) number of quantiles and (ii) distance between initial and base year. The longer the time period, the smaller is the immobility ratio. The

\footnotetext{
${ }^{8}$ However, measures of mobility with a focus on proximity to diagonal axis it not wholly unproblematic. For example, significance of a jump of one quintile depends on the location in the distribution - end quintiles are limited in their movements (Atkinson et al., 1992).
} 
determinant index is defined as $1-|\mathbf{M}|^{1 /[\mathbf{n}-1]}$. Both the Prais index and the determinant index are bounded between 0 and 1: if there is perfect mobility, these two indices converge to unity.

The above three aggregate indices give no indication of how many quantiles a mover moves. In this respect, the cell-related indices -- mean absolute and normalized jump -- are superior: they provide a measure of the number of quantiles that the typical member of a class would jump between two periods. For example, "average absolute jump" calculates the mean number of quantiles moved in absolute value. Like the previous indicators of mobility, these two indices are also sensitive to the choice of the range over which movement is measured i.e. quintiles, ventiles and so on (Fields, 2000).

Lastly, while we estimate all six indices, for the sake of brevity, only four are used throughout the paper. These are: correlation coefficient, Prais index, Atkinson et al. mobility ratio and average jump index. This omission (of two indices) has no implication for our analysis as all the six mobility indicators were found to yield a nearly consistent ranking of the transition matrices for our data.

\section{$4 \quad$ Data}

The data used in this study comes from the ICDDR,B which has maintained a demographic surveillance system (DSS) in the Matlab thana since 1966. We use a random sample of 12015 male-headed households extracted from the database on the Matlab Socioeconomic Census (MSEC) 1996, a complete census of the study villages carried out by the ICDDR,B. These households belonged to 2687 baris $^{9}$ in the Matlab thana. The MSEC 1996 sample data does not automatically yield past records on parental characteristics (such as age and education) and outcomes (such as

\footnotetext{
${ }^{9}$ Baris usually consist of a cluster of households in close physical proximity linked in many instances in a kin-network. In 1996, there were a total of 7440 baris in the Matlab thana.
} 
occupations and asset portfolio). We retrospectively extracted this from earlier rounds of the MSEC. For a total of 10430 male-headed households in the MSEC 1996 sample we were able to extract complete parental and past socio-economic records implying an attrition rate of $13.2 \%$.

For our empirical analysis, we use this dataset to construct two analytical samples. The first sample consists of male heads whose fathers were also present in the study area as a household head in 1974. This contains 5044 sons (47\% of whom head split-off households) for whom we have complete contemporaneous data on their households and retrospective information on their parents and household of origin in childhood. We use this sample to study intergenerational mobility. The second sample_has repeated data on adult sons. This comprises of 4048 male heads of households in 1996 who remained heads in earlier census rounds (i.e. in 1974 and 1982) in Matlab area. We use this sample to examine inter-temporal mobility. The Appendix describes the construction of the working sample in detail.

Lastly, Matlab censuses did not contain data on value of the household assets. Therefore, we constructed an aggregate measure of household wealth by combining data on ownership of various assets, quality of dwelling, usage and sources of water. The Appendix includes a detailed note explaining the method used to create the wealth index.

\section{$5 \quad$ Results and discussion}

\section{$5.1 \quad$ Intergenerational wealth mobility}

\section{Transition matrix analysis}

Table 1 reports the wealth (quintile) transition matrices for the sample of father-son pairs. Sons are represented in the columns against fathers' rows. For each son, the matrices give us the probability of being in a certain wealth quintile 
conditional on father's position in his wealth distribution. Hence, the row probabilities add up to 1 . On the basis of the raw data, movement appears to be restricted to individuals who are initially better-off (in terms of parental position). The chi-square test statistics have large values (all significant at 1\% level) indicating substantial timedependence. However, without correction for age of the individuals, these matrices are confounded by life-cycle effects ${ }^{10}$. Indeed the age-adjusted transition matrix exhibits greater mobility compared to that for the raw data. Substantial persistence remains nevertheless, particularly at the two ends of the wealth distribution. The probability that sons of the poorest stay poor is 0.34 . Likewise, sons of the richest fathers stay richest in $36 \%$ cases. In general, immobility is much higher in the highest and the lowest wealth quintiles than in the middle.

In Table 1, we additionally compute three transition matrices using residuals from the OLS regressions with control for key determinants of son's wealth. To be precise, we incrementally adjust son's wealth data for his educational attainment, occupation and household size. Comparison of the age-adjusted transition matrix to these latter matrices provides a crude way to understand how persistence in education and occupation and shocks to fertility over time may have affected mobility in wealth. For example, convergence of (transition) cell probabilities to the neighbourhood of 0.20 with an additional control for, say, education, would suggest that lower educational mobility is associated with immobility in raw/age-adjusted wealth data.

\footnotetext{
${ }^{10}$ Given that data on fathers and sons are from 1974 and 1996 respectively, this problem is somewhat less serious in our data.
} 
Table 1: Father-son wealth transition matrices

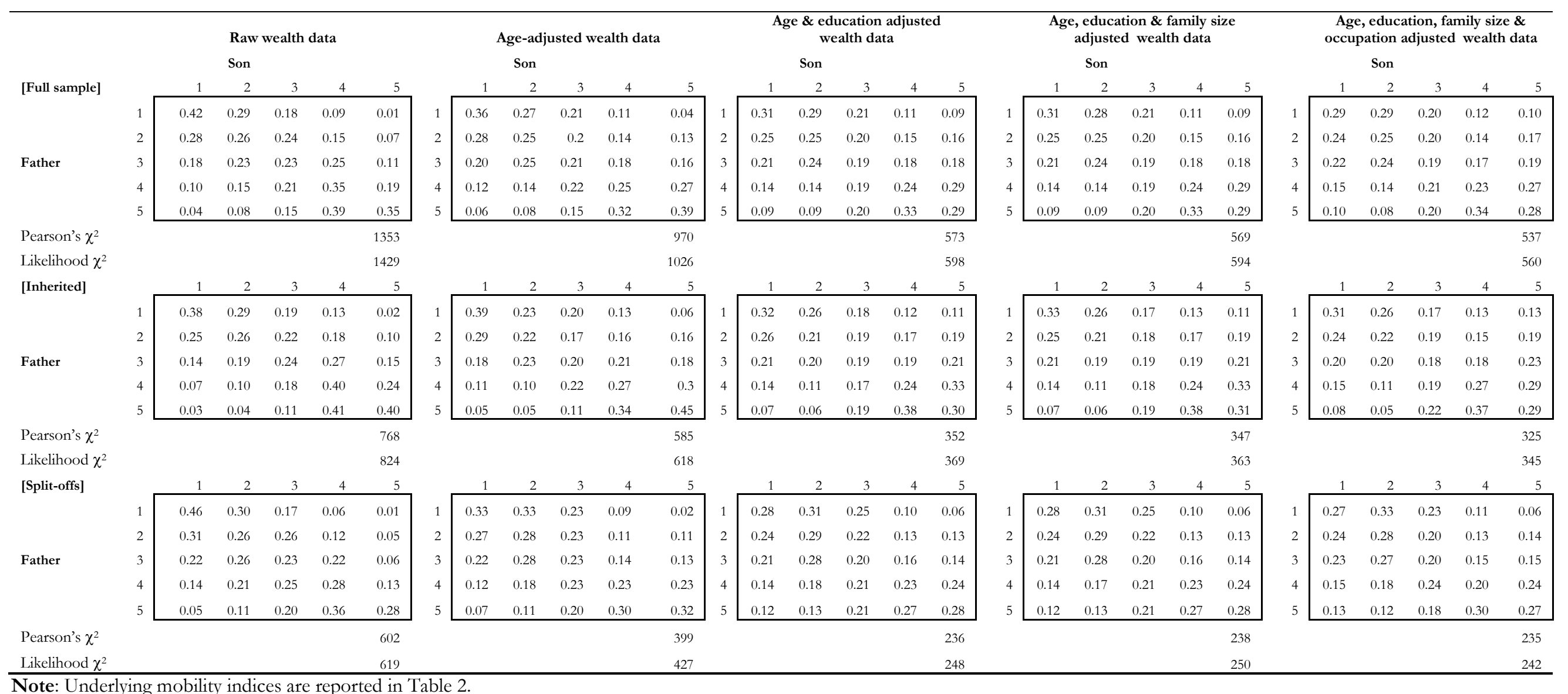


Indeed a large number of the cell probabilities converge to values in the neighbourhood of 0.20 , particularly on and around the principal diagonal. The largest drop in cell probabilities, particularly at the extreme end of the wealth distribution, occurs when we adjust for son's educational attainment. This is also evident from the drop in chi-square values of likelihood statistics, a measure of time dependence. The relatively marginal drop in cell probabilities following additional control for son's occupation is not surprising given that we already control for education and it is the human capital development of sons that may have facilitated occupational mobility from farm to non-farm activities, particularly for the poor fathers. Hence, of all the characteristics, son's education appears to be the key to mobility in wealth.

However, as pointed our earlier, it is difficult to compare the degree of relative mobility for different samples only on the basis of the underlying transition matrices or indicators of time dependence (such as chi-square tests). Some corresponding summary statistics (of positional movement) are required for the purpose of ranking the matrices. We therefore turn to indices of mobility presented in Table 2. Column 1 reports the indices that correspond to transition matrix for raw wealth data while columns 2-5 incrementally adjust son's wealth data for various covariates of wealth. As we move across the columns from left to right, there is an increase in the value of the indices for all samples. The observed increase in mobility thus highlights the underlying forces for initial persistence in wealth in raw data. 
Table 2: Indices of wealth mobility, father-son pairs

\begin{tabular}{llrrrrr}
\hline & & 1 & 2 & 3 & 4 & 5 \\
\cline { 2 - 6 } Full sample & Correlation coefficient & 0.50 & 0.43 & 0.30 & 0.30 & 0.28 \\
& Prais index & 0.84 & 0.88 & 0.93 & 0.93 & 0.93 \\
& Atkinson et al. Mobility Ratio & 0.26 & 0.30 & 0.35 & 0.35 & 0.36 \\
& Average Jump & 1.02 & 1.14 & 1.27 & 1.27 & 1.29 \\
& & & & & & \\
Inherited & Correlation coefficient & 0.51 & 0.45 & 0.31 & 0.31 & 0.29 \\
Households & Prais index & 0.83 & 0.86 & 0.93 & 0.93 & 0.93 \\
& Atkinson et al. Mobility Ratio & 0.25 & 0.29 & 0.35 & 0.35 & 0.36 \\
& Average Jump & 1.00 & 1.12 & 1.27 & 1.27 & 1.29 \\
Spilt-off & & & & & & \\
households & Correlation coefficient & 0.50 & 0.40 & 0.28 & 0.29 & 0.27 \\
& Prais index & 0.87 & 0.90 & 0.93 & 0.93 & 0.94 \\
& Atkinson et al. Mobility Ratio & 0.27 & 0.31 & 0.35 & 0.35 & 0.36 \\
& Average Jump & 1.07 & 1.16 & 1.27 & 1.27 & 1.29 \\
\hline Note: column
\end{tabular}

Note: column 1 refers to raw data; column 2 uses age (and age squared) adjusted residuals from OLS regressions; column 3 uses age and education adjusted data; columns 4 \& 5 additionally adjust for family-size and occupation respectively (using OLS residual).

To get a better idea about the extent of mobility displayed by various matrices, reported values of the indices need to be compared with values assumed under "perfect mobility". The correlation coefficient ranges from 0 to 1 (no mobility) so that the value of 0.50 for the full sample implies that $50 \%$ of the variation in son's wealth is attributable to his father's wealth. When the transition matrix is defined in terms of deciles, the expected average jump in a state of perfect mobility is 3.30 ; where quintiles are used, this benchmark is scaled down to 1.65. Thus the range of "average jump" index from 1.02 to 1.29 for the full sample represents $64 \%$ to $96 \%$ of the value under perfect mobility. Similarly, when there is perfect mobility, all transition probabilities are equal to 0.20 so that Atkinson et al index, Shorrocks' MET and determinant index converge to a value of $0.52,1$ and 1 respectively. As evidenced in Table 2, Atkinson et al. index shoots from about 0.30 (age-adjusted data, column 2) to 0.36 (OLS residuals with age, education, occupation and family size adjustments, column 5). This is equivalent to $11 \%$ increase in mobility. Nevertheless, careful 
comparison confirms our earlier finding that control for son's education leads to most of the gains in mobility.

We also implemented various robustness checks to verify the above results. To check the sensitivity of our results to measurement error, we also used residuals from median regressions ${ }^{11}$. However, our results go through. We additionally controlled for inheritance of headship and tested whether the results were affected by the endogeneity of certain covariates (e.g. family size and inheritance of headship). To this end, residuals from IV regressions were used to compute the transition matrices for the full sample. Once again, our results remained robust.

Turning to results for various sub-samples, the same pattern holds for the sample of sons who head inherited households and split-offs. Initially, the mobility indices (computed using raw as well as age-adjusted wealth data) have slightly higher values for split-offs suggesting that moving out of parent's household leads to greater mobility. However, once we additionally adjust wealth data for education, family size, and occupation, almost all the indices converge to same set of values (columns 3-5). This is particularly evident as we look at the transition probabilities in Table 1 for these three samples. After detailed control, a large number of the cell probabilities converge to a value in the neighbourhood of 0.20 , the perfect mobility benchmark for cell probabilities. Once again, the largest fall follows from additional control for son's educational attainment suggesting that, like the full sample, education remains the key drivers of mobility for the sub-samples.

\footnotetext{
${ }^{11}$ Compared to OLS, median regressions are more robust to outliers.
} 


\section{Regression analysis}

Table 3 reports regression estimates of (mean) persistence in wealth for the full sample. The sample characteristics along with descriptive statistics of the wealth indices are reported in Appendix Table A2. The OLS estimate of father-son persistence falls from 0.53 (column 1) to 0.35 (column 2) as we additionally control for son's age, education, family size and occupation. However, the largest fall occurs when we add the education variable. Despite significant occupational transitions observed in the Matlab villages over the last three decades, occupational mobility does not seem to have any impact on wealth mobility. To test this more explicitly, we re-ran column 2 specification (with and without control for son's education) additionally controlling for father's occupation so that the coefficients on son's occupations would capture the effect of occupational change across generations (results not shown). In neither of the two experiments, the coefficient on father's wealth changed significantly confirming that occupational mobility did not contribute to wealth mobility in our data. 
Table 3: Regression estimates of intergenerational correlation in wealth [Dependent variable: son's wealth]

\begin{tabular}{|c|c|c|c|c|c|c|c|c|c|c|c|c|c|}
\hline & $\begin{array}{r}1 \\
\text { OLS } \\
\end{array}$ & $\begin{array}{r}2 \\
\text { OLS } \\
\end{array}$ & $\begin{array}{r}3 \\
\text { IV } \\
\end{array}$ & $\begin{array}{r}4 \\
\text { IV }\end{array}$ & $\begin{array}{r}5 \\
\text { OLS } \\
\end{array}$ & $\begin{array}{r}6 \\
\text { IV }\end{array}$ & $\begin{array}{r}7 \\
\text { IV } \\
\end{array}$ & $\begin{array}{r}8 \\
\text { FE } \\
\end{array}$ & $\begin{array}{r}9 \\
\text { FE-IV }\end{array}$ & $\begin{array}{r}10 \\
\text { FE-IV }\end{array}$ & $\begin{array}{r}11 \\
\mathbf{F E} \\
\end{array}$ & $\begin{array}{r}12 \\
\text { FE-IV } \\
\end{array}$ & $\begin{array}{r}13 \\
\text { FE-IV }\end{array}$ \\
\hline Father's wealth & $\begin{array}{r}0.538 \\
(50.14)^{* *}\end{array}$ & $\begin{array}{r}0.357 \\
(28.21)^{* *}\end{array}$ & $\begin{array}{r}0.546 \\
(9.06)^{* *}\end{array}$ & $\begin{array}{r}0.476 \\
(6.57)^{* *}\end{array}$ & $\begin{array}{r}0.37 \\
(29.03)^{* *}\end{array}$ & $\begin{array}{r}0.444 \\
(6.03)^{* *}\end{array}$ & $\begin{array}{r}0.492 \\
(8.32)^{* *}\end{array}$ & $\begin{array}{r}0.303 \\
(15.30)^{* *}\end{array}$ & $\begin{array}{r}0.49 \\
(4.12)^{* *}\end{array}$ & $\begin{array}{r}0.561 \\
(6.47)^{* *}\end{array}$ & $\begin{array}{r}0.292 \\
(14.78)^{* *}\end{array}$ & $\begin{array}{r}0.457 \\
(3.73)^{* *}\end{array}$ & $\begin{array}{r}0.535 \\
(6.09)^{* * *}\end{array}$ \\
\hline Schooling & & $\begin{array}{r}0.047 \\
(20.48)^{* *}\end{array}$ & $\begin{array}{r}0.034 \\
(7.13)^{* *}\end{array}$ & $\begin{array}{r}0.041 \\
(6.99)^{* * *}\end{array}$ & $\begin{array}{r}0.048 \\
(20.75)^{* *}\end{array}$ & $\begin{array}{r}0.042 \\
(7.09)^{* * *}\end{array}$ & $\begin{array}{r}0.038 \\
(7.48)^{* * *}\end{array}$ & $\begin{array}{r}0.042 \\
(14.71)^{* * *}\end{array}$ & $\begin{array}{r}0.037 \\
(5.81)^{* * *}\end{array}$ & $\begin{array}{r}0.032 \\
(6.86)^{* * *}\end{array}$ & $\begin{array}{r}0.033 \\
(10.82)^{* * *}\end{array}$ & $\begin{array}{r}0.03 \\
(4.79)^{* * *}\end{array}$ & $\begin{array}{r}0.025 \\
(5.33)^{* *}\end{array}$ \\
\hline Household size & & $\begin{array}{r}0.049 \\
(12.98)^{* *}\end{array}$ & $\begin{array}{r}0.049 \\
(12.49)^{* *}\end{array}$ & $\begin{array}{l}-0.083 \\
(2.24)^{*}\end{array}$ & $\begin{array}{r}0.046 \\
(12.07)^{* *}\end{array}$ & $\begin{array}{r}-0.101 \\
(2.64)^{* *}\end{array}$ & $\begin{array}{l}-0.082 \\
(2.42)^{*}\end{array}$ & $\begin{array}{r}0.057 \\
(11.89)^{* *}\end{array}$ & $\begin{array}{l}-0.141 \\
(1.63)\end{array}$ & $\begin{array}{r}-0.06 \\
(0.94)\end{array}$ & $\begin{array}{r}0.057 \\
(11.99)^{* * *}\end{array}$ & $\begin{array}{r}-0.154 \\
(1.75)+\end{array}$ & $\begin{array}{l}-0.068 \\
(1.08)\end{array}$ \\
\hline Self-employed, non- agriculture & & $\begin{array}{r}-0.066 \\
(3.44)^{* *}\end{array}$ & $\begin{array}{r}-0.037 \\
(1.67)+\end{array}$ & $\begin{array}{r}-0.068 \\
(2.59)^{* * *}\end{array}$ & $\begin{array}{r}-0.021 \\
(1.18)\end{array}$ & $\begin{array}{r}-0.068 \\
(2.58)^{* * *}\end{array}$ & $\begin{array}{l}-0.057 \\
(2.29)^{*}\end{array}$ & $\begin{array}{r}-0.017 \\
(0.73)\end{array}$ & $\begin{array}{r}-0.038 \\
(1.24)\end{array}$ & $\begin{array}{r}-0.033 \\
(1.2)\end{array}$ & $\begin{array}{r}-0.021 \\
(0.91)\end{array}$ & $\begin{array}{r}-0.045 \\
(1.41)\end{array}$ & $\begin{array}{r}-0.039 \\
(1.4)\end{array}$ \\
\hline Wage-employed, non-agriculture. & & $\begin{array}{r}-0.086 \\
(4.33) * *\end{array}$ & $\begin{array}{l}-0.055 \\
(2.43)^{*}\end{array}$ & $\begin{array}{r}-0.106 \\
(3.52)^{* * *}\end{array}$ & $\begin{array}{l}-0.046 \\
(2.42)^{*}\end{array}$ & $\begin{array}{r}-0.109 \\
(3.60)^{* * *}\end{array}$ & $\begin{array}{r}-0.094 \\
(3.39)^{* *}\end{array}$ & $\begin{array}{r}-0.024 \\
(1.08)\end{array}$ & $\begin{array}{l}-0.066 \\
(1.97)^{*}\end{array}$ & $\begin{array}{c}-0.049 \\
(1.72)+\end{array}$ & $\begin{array}{r}-0.03 \\
(1.26)\end{array}$ & $\begin{array}{l}-0.076 \\
(2.21)^{*}\end{array}$ & $\begin{array}{l}-0.058 \\
(2.01)^{*}\end{array}$ \\
\hline Wage-employed, agricultural. labour & & $\begin{array}{r}-0.221 \\
(7.50)^{* * *}\end{array}$ & $\begin{array}{r}-0.189 \\
(5.97)^{* *}\end{array}$ & $\begin{array}{r}-0.282 \\
(6.26)^{* * *}\end{array}$ & $\begin{array}{r}-.218 \\
(6.99)^{* *}\end{array}$ & $\begin{array}{r}-0.289 \\
(6.33)^{* *}\end{array}$ & $\begin{array}{r}-0.268 \\
(6.39)^{* *}\end{array}$ & $\begin{array}{r}-.205 \\
(5.41)^{* *}\end{array}$ & $\begin{array}{r}-0.292 \\
(4.27)^{* * *}\end{array}$ & $\begin{array}{r}-0.238 \\
(4.40)^{* *}\end{array}$ & $\begin{array}{r}-.211 \\
(5.60)^{* *}\end{array}$ & $\begin{array}{r}-0.307 \\
(4.39)^{* *}\end{array}$ & $\begin{array}{r}-0.249 \\
(4.59)^{* *}\end{array}$ \\
\hline OUemp & & $\begin{array}{c}-0.109 \\
(1.90)+\end{array}$ & $\begin{array}{r}-0.084 \\
(1.42)\end{array}$ & $\begin{array}{c}-0.139 \\
(1.89)+\end{array}$ & $\begin{array}{r}-0.083 \\
(1.48)\end{array}$ & $\begin{array}{l}-0.165 \\
(2.20)^{*}\end{array}$ & $\begin{array}{l}-0.154 \\
(2.17)^{*}\end{array}$ & $\begin{array}{r}-0.077 \\
(1.2)\end{array}$ & $\begin{array}{c}-0.168 \\
(1.98)^{*}\end{array}$ & $\begin{array}{r}-0.142 \\
(1.91)+\end{array}$ & $\begin{array}{c}-0.078 \\
(1.22)\end{array}$ & $\begin{array}{l}-0.175 \\
(2.03)^{*}\end{array}$ & $\begin{array}{c}-0.147 \\
(1.99)^{*}\end{array}$ \\
\hline Inherited household & & & & & $\begin{array}{r}0.095 \\
(6.04)^{* *}\end{array}$ & $\begin{array}{r}0.207 \\
(6.79)^{* *}\end{array}$ & $\begin{array}{r}0.227 \\
(4.28)^{* *}\end{array}$ & $\begin{array}{r}0.049 \\
(2.81)^{* *}\end{array}$ & $\begin{array}{r}0.171 \\
(3.32)^{* *}\end{array}$ & $\begin{array}{r}0.175 \\
(2.29)^{*}\end{array}$ & $\begin{array}{r}0.052 \\
(3.03)^{* *}\end{array}$ & $\begin{array}{r}0.179 \\
(3.42)^{* *}\end{array}$ & $\begin{array}{r}0.185 \\
(2.42)^{*}\end{array}$ \\
\hline Spousal education & & & & & & & & & & & $\begin{array}{r}0.026 \\
(7.48)^{* * *}\end{array}$ & $\begin{array}{r}0.025 \\
(5.21)^{* * *}\end{array}$ & $\begin{array}{r}0.024 \\
(5.91)^{* *}\end{array}$ \\
\hline Constant & $\begin{array}{r}1.031 \\
(71.20)^{* *}\end{array}$ & $\begin{array}{r}0.882 \\
(7.63)^{* * *}\end{array}$ & $\begin{array}{r}0.769 \\
(6.15)^{* *}\end{array}$ & $\begin{array}{r}0.433 \\
(2.70)^{* *}\end{array}$ & $\begin{array}{r}0.795 \\
(6.90)^{* * *}\end{array}$ & $\begin{array}{r}0.372 \\
(2.27)^{*}\end{array}$ & $\begin{array}{r}0.397 \\
(2.49)^{*}\end{array}$ & $\begin{array}{r}1.224 \\
(8.60)^{* *}\end{array}$ & $\begin{array}{l}0.437 \\
(1.25)\end{array}$ & $\begin{array}{r}0.645 \\
(2.25)^{*}\end{array}$ & $\begin{array}{r}1.226 \\
(8.69)^{* *}\end{array}$ & $\begin{array}{r}0.42 \\
(1.18)\end{array}$ & $\begin{array}{r}0.636 \\
(2.21)^{*}\end{array}$ \\
\hline Adjusted $\mathrm{R}^{2}$ & 0.29 & 0.39 & & & 0.39 & & & 0.25 & & & 0.26 & & \\
\hline Bari fixed effects & No & No & No & No & No & No & No & Yes & Yes & Yes & Yes & Yes & Yes \\
\hline Over-identification test & - & - & 0.35 & 0.04 & - & 0.25 & 0.28 & - & 0.09 & 0.01 & - & 0.13 & 0.01 \\
\hline Exogeneity test & - & - & 0 & 0 & - & 0 & 0 & - & 0 & 0 & - & 0 & 0 \\
\hline $\mathrm{N}$ & 5044 & 5044 & 5044 & 5044 & 5044 & 5044 & 5044 & 5044 & 5044 & 5044 & 5044 & 5044 & 5044 \\
\hline
\end{tabular}

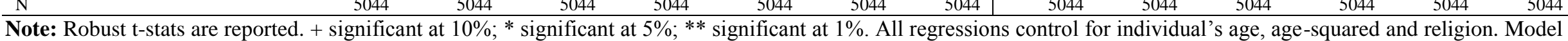
(3) instruments father's wealth (in 1974) by father's occupation and education. Models 4 and 6 additionally instrument son's family size by "treatment area dummy" and "sex of eldest child" (of the son). In addition to father's wealth and son's family size, Model 7 also instruments household inheritance by i) head's birth order (in 1974) and (ii) difference between head's schooling and the maximum of that among his siblings. Model 8-13 repeats models (5)-(7) with bari fixed effects (1775 dummies) and with and without control for spousal education. Test of exogeneity (of instrumented variables i.e. father's wealth, son's household size and so on) is based on Durbin-Wu-Hausman test with the null that the variable is exogenous. Over-identification test (overid) is based on Hansen's J-statistics. Only p-values are reported for the two tests. 
It may be recalled that inclusion of father's wealth and son's family size are problematic due to the problem of measurement error and the endogeneity respectively ${ }^{12}$. To examine the bias in our regression estimate of wealth persistence, model 3 jointly instruments father's wealth and son's family size. Excluded instruments are father's education and two occupation dummies (indicating participation in self-employment in agriculture and non-agriculture). The instruments for family size are (i) a treatment area dummy and (ii) a dummy indicating whether sex of first child is a son ${ }^{13}$. Instrumenting father's wealth always leads to a significant increase in our estimate of persistence in wealth. Durbin-Wu-Hausman test statistic comfortably rejects the exogeneity of father's wealth in all cases. This finding tends to support the view that OLS estimates are possibly downward biased due to the presence of measurement error.

However, given the nature of our excluded instruments, it is not possible to be conclusive about the exact source of any potential bias. The use of occupation and education as excluded instruments for father's wealth implies that the IV estimate of the coefficient on father's wealth reflects father-son persistence in the earned income or measured portion of wealth (as predicted by his human capital and occupational choices). Like father's wealth, these two instruments remain potentially correlated with unobserved earnings endowment (such as innate ability) that is common between fathers and sons. If true, father's wealth is endogenous and the reported IV estimates are unlikely to be robust to such problem.

Interestingly, the inclusion of the son's family size variable has no effect on the size of the coefficient on father's wealth, even when we treat family size as

\footnotetext{
${ }^{12}$ However, as pointed out before, father's wealth could be additionally endogenous.

${ }^{13}$ We estimated separate models where we individually treated father's wealth and son's family size as endogenous. In both cases, our instruments comfortably passed the over-identification test. However, for the sake of brevity, we have suppressed these results.
} 
endogenous. The latter has a significant effect on son's wealth $(+v e$ in OLS specification and -ve in IV). Durbin-Wu-Hausman test statistic comfortably rejects the exogeneity of family size in all cases at 5\% level. The excluded instruments are always highly significant in the first stage regressions and pass the validity test in 8 out of 12 cases $^{14}$. Models 5 and 6 further expand the regression specification with control for inheritance of household headship. Model 7 additionally instruments the headship inheritance dummy by two (retrospective) measures of within household inequality.

Models 8-13 in the Table 3 extend models 2-7 with additional control for bari fixed effects. These fixed effects wipe out correlation between households that are located in the same bari. Within-bari correlation in household wealth arises because some of the households were joint in recent past and therefore, may have shared significant economic ties. As a further robustness check, we repeated our analysis with additional indices of household wealth, constructed following the principal component analysis ${ }^{15}$ and weights derived from expenditure regression (results suppressed $)^{16}$. However, our findings go through.

It may be recalled that the father's wealth variable is a generated regressor in our model so that inference may be incorrect. This is particularly a problem if $\mathrm{t}$ statistics are marginally significant and standard errors are biased downwards. The tstatistics reported in Table 3 are very large for all of the key variables of interest, particularly father's wealth. We therefore test whether our inference is compromised by bootstrapping the standard errors (results not shown). However, our earlier

\footnotetext{
${ }^{14}$ However, they pass in all cases only if IV regressions with endogenous family size and uninstrumented parental wealth are considered.

${ }^{15}$ There is no consensus on the choice of the number of factors. We followed the existing practice and chose the first factor.

${ }^{16}$ To be precise, an alternative set of coefficients as weights was obtained by regressing household per capita expenditure on indicators of household quality and assets with additional control for schooling of head and his spouse.
} 
conclusions hold; while bootstrapped standard errors in some cases yield smaller tstatistics, they still remain significant at the conventional level.

Similar results are reported for sons who head split-offs and inherited households (see Appendix, Table A3). Simultaneously correcting for the measurement error in father's wealth and endogeneity of son's family size and controlling for all other covariates, the resulting estimates suggest higher persistence for sons heading inherited households. However, it is not known whether the difference in persistence with the split-offs is significant at conventional levels.

\subsection{Inter-temporal mobility in wealth}

Compared to intergenerational mobility, inter-temporal mobility is primarily affected by life-cycle events such as variation in the size and the composition of the household. The level of savings varies across the life cycle: younger heads have lower savings and earnings, which tend to peak in the middle of the life cycle. By then, the dependency ratio also alters favourably as adult sons enter the labour market. However, at retirement, savings start to deplete. The process of household partition sets in when sons separate from the patriarch. This altogether could create downward mobility, due to the loss of household economies of scale in consumption and production (Drèze et al. 1998). In contrast to these life-cycle factors, the role of unobservables is, however, limited. Since ability is likely to be more correlated between periods of an individuals' life than between generations of a family, one would expect greater intergenerational mobility than inter-temporal mobility. 
Table 4: Indices of mobility in wealth, 1974-1996

\begin{tabular}{lrrrrr}
\hline & 1 & 2 & 3 & 4 & 5 \\
\cline { 2 - 5 } Correlation coefficient & 0.53 & 0.52 & 0.38 & 0.38 & 0.37 \\
Prais index & 0.84 & 0.84 & 0.90 & 0.90 & 0.91 \\
Atkinson et al. mobility ratio & 0.26 & 0.26 & 0.33 & 0.33 & 0.34 \\
Average jump & 1.04 & 1.04 & 1.19 & 1.19 & 1.22 \\
\hline
\end{tabular}

Note: column 1 refers to raw data; column 2 uses age and age squared adjusted data (residuals from OLS regressions); column 3 additionally adjusts for education; columns 4 \& 5 additionally correct wealth data for family-size and occupation (using residuals from OLS) respectively.

Table 4 presents the results. For the sake of brevity, we do not report the transition matrices; only the corresponding indices of mobility are presented. For this sample, the principal cause of mobility is life cyclical and emanates from the permanent income hypothesis. Individuals tend to experience low mobility earlier in life. Income increases with age, but at retirement it declines as savings are depleted and transfers are made to progeny. Similar to our analysis of intergenerational mobility, we report transition matrix with corrections for age, as some individuals are likely to be in the middle of their life cycle in 1974 . There is substantial persistence in an inter-temporal context: individuals with poor initial wealth tend to be worse-off later in life. Given the gap of 22 years between the base period and the final period, time dependence is substantial. This is true even after adjusting for changes in the family size and controlling for an individual's age. Once we adjust for educational attainment, the probability of being on the diagonal axis is substantially reduced, perhaps implying that the lack of education also limits mobility during one's life cycle. This is similar to intergenerational mobility, where persistence weakens once such adjustments are made. Furthermore, a comparison of intergenerational and intertemporal mobility indices (Table 2 vs. Table 4) suggests that persistence is not necessarily greater in an inter-temporal context. To the extent ability is more correlated between periods of a person's life than generations of the same family, this 
finding suggests that ability plays a smaller role in determining economic mobility in rural Bangladesh.

\subsection{Intergenerational schooling mobility}

Since the distribution of schooling in 1974 was skewed (i.e. the majority of fathers being uneducated), we do not compute the quantile transition matrix. Instead, we classify individuals in five distinct groups on the basis of their levels of schooling. These are: no education, less than primary education (grade 1-4 completion), primary education (grade 5 completion), junior secondary education (grade 6-8) and secondary education (grade 9 and above). The resultant transition matrices of schooling for the sample of father-son pairs are reported in the Appendix Table A4. The corresponding indices of mobility/immobility are reported in Table 5.

Table 5: Indices of schooling mobility, father-son pairs

\begin{tabular}{|c|c|c|c|}
\hline & All sons & Inherited & Split-offs \\
\hline Correlation coefficient & 0.39 & 0.40 & 0.35 \\
\hline Prais index & 0.83 & 0.82 & 0.86 \\
\hline Atkinson et al. mobility ratio & 0.32 & 0.31 & 0.35 \\
\hline Average jump & 1.17 & 1.13 & 1.25 \\
\hline
\end{tabular}

Intergenerational persistence is very high among sons of uneducated fathersalmost $60 \%$ of them stay uneducated whilst only $14 \%$ manage to obtain education beyond primary schooling. Interestingly, split-offs have less time independence than sons who head inherited households (as indicated by relatively smaller values of chisquare test statistics). This is consistent with the larger values of the mobility indices for split-offs indicating greater positional movement. Using the benchmark figures of these indices under the state of perfect mobility, it is possible to assess the relative mobility experienced by individuals in different samples. For example, the "average jump" index yields $68 \%$ mobility for inherited household heads compared to $75 \%$ for 
split-offs ${ }^{17}$. Similarly, The Atkinson et al. index yields $59 \%$ mobility for inherited household heads compared to $67 \%$ for split-offs ${ }^{18}$. The value of correlation coefficient is 0.39 for the full sample and implies that $39 \%$ of the variation in son's education is attributable to variation in the father's schooling.

However for the split-offs, the direction of mobility is mostly downward-- the probability of descending from the top group to the bottom (i.e. staying uneducated when fathers have completed secondary education or above) is 0.19 compared to only 0.07 for the sample of inherited households. Our finding that sons who experience greater downward mobility in schooling are also heads of split-offs is consistent with Foster and Rosenzweig (2001). For Indian data, they report that sons who splinter from parents have lower school attainment compared to those who headed intact households.

Given the evidence of a lack of intergenerational mobility in schooling, one is interested to know whether schooling persistence has declined over time and its implications economic mobility. The relationship between schooling mobility and earnings (economic) mobility has been formalised in a simple model discussed in Solon (2004). This can be summarised using the following relationships:

$$
\begin{aligned}
& \text { Earnings }_{\mathrm{t}}=\phi \text { schooling }_{\mathrm{t}} \quad+\varepsilon_{t} \ldots \ldots \ldots[3] \\
& \text { Schooling }_{\mathrm{t}}=\psi(\text { Parental income })_{\mathrm{t}-1}+\mathrm{v}_{\mathrm{t}} \ldots \ldots . .[4] \\
& \text { Earnings }_{\mathrm{t}}=\phi \psi(\text { Parental income })_{\mathrm{t}-1}+\omega_{\mathrm{t}} \ldots \ldots \text { [5] } \\
& {\left[\omega_{\mathrm{t}}=\phi v_{t}+\varepsilon_{\mathrm{t}}\right]}
\end{aligned}
$$

Equation (3) specifies earnings as a function of schooling attainment whilst equation (4) expresses schooling as a function of parental income. The parameters $\phi$ and $\psi$ stand for labour market returns to education and elasticity of schooling with respect to

\footnotetext{
${ }^{17}$ These figures are computed by comparing the raw values to the benchmark figure (under perfect mobility) of 1.65 .

${ }^{18}$ These figures are computed by comparing the raw values to the benchmark figure (under perfect mobility) of 0.52 .
} 
parental wealth, respectively. If we combine equations (3) and (4) by expressing earnings as a function of parental wealth, equation (3) reduces to equation (5). According to Solon, the intergenerational mobility parameter is now $\Phi \Psi$. This interpretation of the intergenerational correlation has the following implication. Earnings mobility is higher if schooling attainment is sensitive to parental education and the returns to education are positive. Analysis of labour market earnings data suggests that, $\phi$, the average returns to education in Bangladesh is $8 \%$ (Asadullah, 2006). If sensitivity of schooling vis-à-vis parental income distribution (i.e. parameter $\Psi)$ turns out to be high and stable over time, this would undermine economic mobility in the future.

Table 6 reports regression estimates of intergenerational persistence in school completion. The OLS regression of sons' schooling on that of their fathers (with no other covariates included) yields an estimate of 0.51 which drops somewhat with the inclusion of mother's education. The coefficient on father's schooling reduces furthermore to 0.29 with the inclusion of father's wealth. The effect of parental wealth is also evident from the jump in adjusted $\mathrm{R}^{2}$ values (from 0.17 to 0.27 ). However, no further changes occur to the coefficient on father's wealth as we additionally control for father's age, family size, occupation and village of residence. Hence, net of parental wealth and maternal education, the influence of father's schooling on that of the son remains large and significant. 
Table 6: OLS estimates of intergenerational persistence in schooling, 1974 [Dependent variable: son's years of schooling completed]

\begin{tabular}{|c|c|c|c|c|c|c|}
\hline \multirow[t]{2}{*}{1974 sample } & & & & & & \\
\hline & (1) & (2) & (3) & (4) & (5) & (6) \\
\hline \multirow[t]{2}{*}{ Father's education } & 0.515 & 0.416 & 0.290 & 0.290 & 0.285 & 0.273 \\
\hline & $(25.92)^{* *}$ & $(18.50)^{* *}$ & $(12.82)^{* *}$ & $(12.72)^{* *}$ & $(12.53)^{* *}$ & $(12.75)^{* *}$ \\
\hline \multirow[t]{2}{*}{ Mother's education } & & 0.512 & 0.397 & 0.395 & 0.410 & 0.369 \\
\hline & & $(10.04)^{* *}$ & $(8.20)^{* *}$ & $(8.13)^{* *}$ & $(8.44)^{* *}$ & $(8.16)^{* *}$ \\
\hline \multirow[t]{2}{*}{ Father's wealth } & & & 1.897 & 1.863 & 1.767 & 1.858 \\
\hline & & & $(22.10)^{* * *}$ & $(21.55)^{* *}$ & $(19.51)^{* *}$ & $(20.04)^{* *}$ \\
\hline \multirow{2}{*}{ Control for father's family size? } & No & No & No & No & Yes & Yes \\
\hline & No & No & No & No & Yes & Yes \\
\hline Control for father's occupation? & No & No & No & Yes & Yes & Yes \\
\hline Adjusted $\mathrm{R}^{2}$ & 0.15 & 0.17 & 0.27 & 0.27 & 0.27 & 0.26 \\
\hline Village fixed effects & No & No & No & No & No & Yes \\
\hline $\mathrm{N}$ & 4150 & 4150 & 4150 & 4150 & 4150 & 4150 \\
\hline \multicolumn{7}{|l|}{1996 sample } \\
\hline \multirow{3}{*}{ Father's education } & $(1)$ & (2) & (3) & (4) & (5) & (6) \\
\hline & 0.442 & 0.308 & 0.216 & 0.184 & 0.184 & 0.186 \\
\hline & $(33.71)^{* *}$ & $(18.89)^{* *}$ & $(13.58)^{* *}$ & $(12.25)^{* *}$ & $(12.24)^{* *}$ & $(12.36)^{* *}$ \\
\hline \multirow[t]{2}{*}{ Mother's education } & & 0.331 & 0.254 & 0.211 & 0.210 & 0.219 \\
\hline & & $(13.97)^{* *}$ & $(11.23)^{* *}$ & $(9.86)^{* *}$ & $(9.79)^{* *}$ & $(10.15)^{* *}$ \\
\hline \multirow[t]{2}{*}{ Father's wealth } & & & 1.946 & 1.638 & 1.646 & 1.601 \\
\hline & & & $(24.50)^{* *}$ & $(21.49)^{* *}$ & $(21.31)^{* *}$ & $(20.52)^{* *}$ \\
\hline \multirow{2}{*}{ Control for father's family size? } & No & No & No & No & Yes & Yes \\
\hline & No & No & No & No & Yes & Yes \\
\hline $\begin{array}{l}\text { Control for father's age? } \\
\text { Control for father's occupation? }\end{array}$ & No & No & No & Yes & Yes & Yes \\
\hline Adjusted $\mathrm{R}^{2}$ & 0.18 & 0.22 & 0.30 & 0.38 & 0.38 & 0.38 \\
\hline Village fixed effects & No & No & No & No & No & Yes \\
\hline $\mathrm{N}$ & 4924 & 4924 & 4924 & 4924 & 4924 & 4924 \\
\hline
\end{tabular}

Note: (1) Absolute value of $\mathrm{t}$ statistics in parentheses. + significant at 10\%; * significant at 5\%; ** significant at 1\%. (2) In regression models based on 1974 data, sons are restricted to be of school age (aged 24 years or less) whilst sons are restricted to be aged 17-24 years in regressions based on 1996 sample. (3) Regressions include a dummy for missing data on mother's education. (4) Fixed-effects specification controls for village location.

Table 6 therefore confirms that $\Psi$ is large and positive -- schooling attainment is very sensitive to family background in 1974. It is therefore important to ascertain whether $\Psi$ has declined over time. To this end, the bottom panel of Table 6 reports estimates of schooling persistence using data on a sample of household heads and their adult coresident sons in 1996. Clearly, intergenerational persistence in schooling has remained largely stable when we consider correlation for a much younger cohort of school 
graduates. This is evident if we compare the coefficients on father's wealth across 1974 and 1996 samples.

In sum, returns to education are significant and positive in Bangladesh. However, the fact that $\Psi$ has remained stable over time suggests that school attainment in rural Bangladesh is unequally distributed across socio-economic groups. This in turn has limited upward economic mobility and reinforced the process of intergenerational persistence.

\subsection{Intergenerational wealth mobility and occupational diversification}

The results presented in sections 5.1 confirm that occupation mobility is significant in the Matlab region. Yet, its contribution to wealth mobility is found to be limited. This finding is puzzling given significant occupational mobility across generations in our data. As discussed in section 2, there have been significant changes in the sectoral composition of the labour force in the Matlab region during the study period. A large number of individuals switched from agriculture to non-farm activities between 1974 and $1996^{19}$.

The puzzle of weak correlation between occupational and wealth mobility is explained by the fact that much of the occupational mobility out of agriculture is caused by push factors. Sons may have been pushed into low-productivity selfemployment type activities owing to an increase in landlessness in the country. This possibility is also supported by the fact that not all non-farm activities are associated with high income. For instance, Sen (1996) finds that income growth in non-farm sector is higher than that in agricultural wage employment if non-farm wage sector is excluded. For these reasons, therefore, despite transformation of the rural labour force

\footnotetext{
${ }^{19}$ Similar pattern is also documented in Hossain et al. (2002) who study occupational change in rural Bangladesh during 1987-2000.
} 
in Bangladesh, the level of per capita rural non-farm income did not increase (Mahmud, 1996).

In sum, it is indeed a puzzle that significant occupational diversification has occurred in the Matlab region despite no impact on intergenerational wealth mobility. This puzzle is explained by the fact much of the occupational change from farm to non-farm activities was owing to push factors. Sons may have been pushed into lowreturn non-farm activities which do not require much human capital. This also explains occupational mobility at a relatively low level of schooling.

\section{Conclusion}

This paper has looked at the nature and extent of wealth mobility among male household-heads in Matlab villages in Bangladesh. While we did not have access to a panel dataset containing repeated information on father-son pairs, we have used retrospective residential records on a sample of current household-heads to track their households of origin and parents. This has been possible by linking census records on household-heads in the Matlab villages in 1996 to their parents on whom data was collected in an earlier census in 1974. By construction, the resultant dataset permits a study of mobility only among those sons who have remained in the study area over the last 22 years. Given that we chose bari as the primary sampling unit for the selection of households, our dataset contains most of the adult sons who currently heads individual households in the study area. However, sample attrition owing to non-random omission of split-offs (moving out of the study area) could still bias the estimates of mobility and its various determinants (Rosenzweig, 2003). This possibility remains an important limitation of our study. In addition to sample attrition problem, the results can be also biased in presence of economic and health shocks to households. Since we do not have data on shocks, the estimates presented for son's 
wealth, son's education and other variables in wealth persistence regressions may suffer from omitted variable bias. With these caveats in mind, the following results emanate from this study.

We find large intergenerational persistence in raw (and age-adjusted) wealth data, particularly at the two tails of the wealth distribution. However, such persistence weakens once we additionally net out contribution of son's education, household inheritance and family size to his wealth. The fall in transition probabilities (on the diagonal axis) is the largest when we adjust for educational attainment, indicating that differential schooling is the key source of persistence in wealth across generations of the same family. The cell probabilities remain largely stable once we occupational differences among fathers and sons are controlled for. Regression analysis of wealth data yields an estimate of father-son wealth elasticity in the range of 0.77 and 0.53 . This is much larger than the existing estimates for developed countries and confirms the commonly held view that economic mobility is in developing societies ${ }^{20}$.

In addition to wealth mobility, we also assess mobility in school completion. Transition matrices reveal that mobility is very low among children of uneducated fathers: almost $60 \%$ of them stay uneducated while only $14 \%$ manage to obtain education beyond primary schooling. Overall, the lack of educational mobility in Matlab villages is striking. And it remains the most important determinant of economic mobility in our data. Comparisons of intergenerational schooling mobility and the elasticity of son's schooling with respect to the father's wealth between two cohorts suggest that schooling persistence has not declined much over time.

\footnotetext{
${ }^{20}$ The estimate for the US data is 0.37 , before the transfer of bequests (Charles and Hurst, 2003). Another study using the US data is Menchik (1979) where the correlation coefficient lies between 0.48 and 0.50 . However, the sample size used is very small.
} 
An additional contribution of this paper is the construction of profiles of generational mobility for sons by inheritance of household headship. As such, we shed some light on a key demographic source of immobility in rural societies: household partition. While moving out of the household of the patriarch creates greater mobility in wealth accumulation for sons, we find that in most cases it is downward. Interestingly, sons who experience greater downward mobility in schooling are those who also head split-offs. This, in part, explains why split-offs tend to experience greater downward mobility in wealth.

The above findings have serious implications for the process of economic development. Large persistence over the life-cycle implies that poverty-trap may exist: individuals who continue with poorer wealth may continue to remain poor over a longer period of time. For many of these individuals, this is unlikely to change across generations, as evidenced in the lack of intergenerational mobility in wealth. One policy option to remove these disadvantages in the initial condition is to equalize educational opportunities. Large scale investment in rural schooling infrastructure undertaken by the government of Bangladesh over the past two decades is therefore well-placed. The success of these investments in raising economic mobility in later life would, nevertheless, depend on the progressivity of these investments i.e. to what extent they facilitate increase schooling attainment for all groups, particularly the children of uneducated and poor parents. 


\section{References}

Angrist, Joshua D. and William Evans (1998) Children and Their Parents' Labor Supply: Evidence from Exogenous Variation in Family Size. American Economic Review, 88(3), pp. 450-77.

Alderman, Harold, Jere R. Behrman, Hans-Peter Kohler, John A. Maluccio, and Susan Cotts Watkins (2001) Attrition in Longitudinal Household Survey Data: Some Tests for Three Developing-Country Samples. Demographic Research, 5(4), pp. 79-124.

Asadullah, M. Niaz (2006) Returns to education in Bangladesh. Education Economics, 14 (4), pp. 457-472.

Atkinson, A. B., François Bourguignon and Christian Morrisson (1992) Empirical Studies on Earnings Mobility (Chur, Philadelphia: Harwood Academic Publishers).

Bourguignon, Francois, Francisco Ferreira and Marta Menedez (2003) Inequality of Outcomes and Inequality of Opportunities". William Davidson Institute Working Paper no. 630.

Charles, Kerwin and Erik Hurst (2003) The Correlation of Wealth Across Generations. Journal of Political Economy, 111(6), pp. 1155-1182.

Drèze, Jean, Peter Lanjouw and Naresh Sharma (1998) Economic Development in Palanpur 1957-93, in: Peter Lanjouw and Nick Stern (eds) Economic development in Palanpur over five decades (Oxford University Press).

Dunn, Christopher (2003) Intergenerational Earnings Mobility in Brazil and its Determinants. University of Michigan, mimeo.

Fields, Garry (2000) Distribution and Development (New York: Russell Sage Foundation).

Foster, Andrew (1993) Household Partition in Rural Bangladesh. Population Studies, 47 (1993), pp. 97-114.

and Mark Rosenzweig (2001) Household Division and Rural Economic Growth. Review of Economic Studies. 69(4), pp. 839-69.

Fuwa, N. (1999) An Analysis of Social Mobility in a Village Community: The Case of a Philippine Village. Journal of Policy Modelling, 21(1), pp. 101-138.

Grawe, Nathan and Casey Mulligan (2002) Economic Interpretations of Intergenerational Correlations. Journal of Economic Perspectives, 16(3), pp. 45-58.

Grawe, Nathan (2004) Intergenerational Mobility for Whom? The Experience of High- and Low-Earnings Sons in International Perspective, In: Miles Corak, (eds) Generational Income Mobility in North America and Europe (Cambridge: Cambridge University Press).

Hossain, Mahabub, Manik Bose, Alamgir Chowdhury and Meinzen-Dick, Ruth (2002). Changes in Agrarian Relations and Livelihood in Rural Bangladesh: Insights from Repeat Village Studies, in: Ramachandran, V.K. and Swaminathan, Madhura (eds) Agrarian Studies: Essays on Agrarian Relations in Less Developed Countries (Tulika Books: New Delhi).

Mahmud, Wahiduddin (1996) Employment Patterns and Income Formation in Rural Bangladesh: The Role of Rural Non-farm Sector. Bangladesh Development Studies, 24(3 \& 4), pp. 1-27.

Menchik, Paul L. (1979) Inter-generational Transmission of Inequality: An Empirical Study of Wealth Mobility. Economica, 46(184), pp. 349-62. 
Rahman, Omar, Jane Manken, Andrew Foster, and Paul Gertler (2001) Matlab Health and Socioeconomic Survey (MHSS), 1996: Overview and User's Guide. (ICPSR: Ann Arbor, Michigan).

Razzaque, Abdur, Lutfun Nahar, A. M. Sarder, J. Ginneken and M.A. Shaikh (1998) Demographic Surveillance System-Matlab, Scientific report no 83. (ICDDR,B: Dhaka).

Rosenzweig, Mark (2003) Payoffs from Panels in Low-Income Countries: Economic Development and Economic Mobility. American Economic Review, 93(2), pp. 112-117.

Sen, Binayak (1996) Rural Non-farm Sector in Bangladesh: Stagnating and Residual, or Dynamic and Potential? Bangladesh Development Studies, 24(3 \& 4), pp. 143-180.

Swaminathan, Madhura (1991) Measuring Mobility in Wealth: Estimates from a South Indian Village. Oxford Bulletin of Economics and Statistics, 53(2), pp. 171-83.

Solon, Gary (2004) A Model of Intergenerational Mobility Variation over Time and Place. In Miles Corak (ed.) Generational Income Mobility in North America and Europe (Cambridge: Cambridge University Press).

(2002) Cross-Country Differences in Intergenerational Earnings Mobility. Journal of Economic Perspective, 16(3), pp. 59-66.

(1992) Intergenerational Income Mobility in the United States. American

Economic Review, 82(3), pp. 393-408.

Thomas, Duncan, Elizabeth Frankenberg, and James P. Smith (2001) Lost but not Forgotten: Attrition and Follow-up in the Indonesia Family Life Survey. Journal of Human Resources 36(3), pp. 556-92.

Walker, Thomas and J. Ryan (1990) Village and Household Economics in India's Semi-arid Tropics (Baltimore: The Johns Hopkins University Press). 
Table A1: Summary statistics and (regression) weights relating to household asset and housing quality variables used in the construction of household wealth index

\begin{tabular}{|c|c|c|c|c|c|c|}
\hline & \multirow{2}{*}{$\begin{array}{c}(1) \\
\text { Asset }\end{array}$} & \multirow{2}{*}{$\begin{array}{c}(2) \\
\text { LnPCE }\end{array}$} & \multicolumn{2}{|c|}{ MHSS, 96} & \multicolumn{2}{|c|}{ MSEC, 96} \\
\hline & & & Mean & SD & Mean & SD \\
\hline Household has a cow & $\begin{array}{l}0.191^{* *} \\
(4.97)^{* *}\end{array}$ & $\begin{array}{c}0.041 \\
(2.10)^{*}\end{array}$ & 0.42 & 0.49 & 0.33 & 0.47 \\
\hline Household has a boat & $\begin{array}{l}0.049 \\
(1.19)\end{array}$ & $\begin{array}{c}0.079 \\
(3.76)^{* *}\end{array}$ & 0.31 & 0.46 & 0.28 & 0.45 \\
\hline Household has a radio & $\begin{array}{c}0.311 \\
(6.93)^{* *}\end{array}$ & $\begin{array}{c}0.103 \\
(4.47)^{* * *}\end{array}$ & 0.48 & 0.50 & 0.39 & 0.49 \\
\hline Household has a watch & $\begin{array}{c}0.129 \\
(2.72)^{* *}\end{array}$ & $\begin{array}{c}0.156 \\
(6.41)^{* *}\end{array}$ & 0.59 & 0.49 & 0.49 & 0.50 \\
\hline Household has a hurricane & $\begin{array}{l}0.106 \\
(1.59)\end{array}$ & $\begin{array}{l}-0.009 \\
(0.25)\end{array}$ & 0.91 & 0.29 & 0.88 & 0.33 \\
\hline Household has a quilt & $\begin{array}{c}0.348 \\
(7.23)^{* *}\end{array}$ & $\begin{array}{c}0.127 \\
(5.13)^{* *}\end{array}$ & 0.62 & 0.48 & 0.54 & 0.50 \\
\hline Roof of largest room made of tin & $\begin{array}{c}0.535 \\
(4.52)^{* *}\end{array}$ & $\begin{array}{l}0.072 \\
(1.18)\end{array}$ & 0.97 & 0.16 & 0.96 & 0.19 \\
\hline Wall of largest room made of tin & $\begin{array}{c}0.656 \\
(14.82)^{* *}\end{array}$ & $\begin{array}{c}0.160 \\
(7.04)^{* *}\end{array}$ & 0.52 & 0.50 & 0.43 & 0.50 \\
\hline Tube well (source of drinking water) & $\begin{array}{c}0.401 \\
(4.75)^{* *}\end{array}$ & $\begin{array}{l}0.023 \\
(0.53)\end{array}$ & 0.95 & 0.22 & 0.94 & 0.24 \\
\hline Tube well (source of cooking water) & $\begin{array}{c}0.221 \\
(1.90)+\end{array}$ & $\begin{array}{l}0.057 \\
(0.95)\end{array}$ & 0.06 & 0.24 & 0.04 & 0.20 \\
\hline Tube well (source of bath water) & $\begin{array}{l}0.171 \\
(1.41)\end{array}$ & $\begin{array}{c}0.142 \\
(2.29)^{*}\end{array}$ & 0.06 & 0.24 & 0.03 & 0.18 \\
\hline Tube well (source of water for washing) & $\begin{array}{c}0.274 \\
(1.75)+ \\
\end{array}$ & $\begin{array}{c}0.221 \\
(2.76) * * \\
\end{array}$ & 0.03 & 0.17 & 0.01 & 0.12 \\
\hline Adjusted $\mathrm{R}^{2}$ & 0.38 & 0.28 & & & & \\
\hline $\mathrm{N}$ & 3423 & 3421 & 3423 & & 5044 & \\
\hline Mean of dependent variable & 10.64 & 9.22 & & & & \\
\hline Stan. Dev. of dependent variable & 1.35 & 0.64 & & & & \\
\hline
\end{tabular}

Note: Absolute value of t-statistics in parentheses. + significant at 10\%; * significant at 5\%; ** significant at $1 \%$. All the variables apart from the dependent variables are dummies. Column (1) refers to the regression where the dependent variable is household asset value. It also controls for education of the head, his spouse and household size. Column 2 (regression using household expenditure as the dependent variable) controls for education of the head and his spouse. Both regressions use data for male-headed households only. 
Table A2: Mean statistics of sample of sons

\begin{tabular}{|c|c|c|c|c|c|c|}
\hline \multirow[b]{2}{*}{ Variable } & \multicolumn{2}{|c|}{ Full } & \multicolumn{2}{|c|}{ Inherit } & \multicolumn{2}{|c|}{ Split-off } \\
\hline & Mean & S.D. & Mean & S.D. & Mean & S.D. \\
\hline Age & 39.00 & 8.72 & 41.33 & 9.39 & 36.42 & 7.07 \\
\hline Age squared & 1597.10 & 745.03 & 1796.90 & 833.59 & 1376.22 & 554.82 \\
\hline Non Muslim & 0.15 & 0.36 & 0.16 & 0.37 & 0.14 & 0.35 \\
\hline Married & 0.96 & 0.20 & 0.94 & 0.23 & 0.97 & 0.16 \\
\hline Household size & 5.50 & 2.00 & 6.00 & 2.22 & 4.94 & 1.55 \\
\hline Spousal education & 1.98 & 2.84 & 2.01 & 2.89 & 1.94 & 2.78 \\
\hline Schooling (numbers of grade completed) & 3.22 & 3.70 & 3.59 & 3.82 & 2.82 & 3.52 \\
\hline Self-employed in agriculture & 0.30 & 0.46 & 0.34 & 0.47 & 0.26 & 0.44 \\
\hline Self-employed in non-agriculture & 0.35 & 0.48 & 0.33 & 0.47 & 0.38 & 0.49 \\
\hline Wage-employed in non-agriculture & 0.23 & 0.42 & 0.23 & 0.42 & 0.24 & 0.43 \\
\hline Wage-employed in (agricultural) labour & 0.07 & 0.25 & 0.06 & 0.24 & 0.08 & 0.27 \\
\hline Unemployed & 0.01 & 0.11 & 0.02 & 0.13 & 0.01 & 0.08 \\
\hline Others & 0.00 & 0.06 & 0.00 & 0.06 & 0.00 & 0.05 \\
\hline OUemp (others + unemployed) & 0.02 & 0.13 & 0.02 & 0.15 & 0.01 & 0.10 \\
\hline First child is a daughter & 0.40 & 0.49 & 0.38 & 0.48 & 0.43 & 0.50 \\
\hline Wealth index & 1.64 & 0.66 & 1.76 & 0.67 & 1.52 & 0.64 \\
\hline Alternative wealth index & 0.39 & 0.23 & 0.43 & 0.24 & 0.35 & 0.22 \\
\hline Residence in treatment area & 0.56 & 0.50 & 0.56 & 0.50 & 0.57 & 0.50 \\
\hline Inherited household & 0.53 & 0.50 & - & - & - & - \\
\hline Birth order (in 1974) & 1.78 & 0.98 & - & - & - & - \\
\hline $\begin{array}{l}\text { Gap between own schooling and maximum of } \\
\text { that among siblings (in 1974) }\end{array}$ & 1.38 & 2.64 & - & - & - & - \\
\hline \multicolumn{7}{|l|}{ Parental characteristics (based on MSEC 1974) } \\
\hline Father's age & 54.72 & 10.79 & - & - & - & - \\
\hline Father's wealth index & 1.14 & 0.66 & 1.17 & 0.66 & 1.10 & 0.66 \\
\hline Father's wealth index (alternative) & 0.27 & 0.19 & 0.28 & 0.19 & 0.26 & 0.19 \\
\hline Father's education & 1.94 & 2.78 & 2.18 & 2.94 & 1.67 & 2.56 \\
\hline Mother's education & 0.36 & 1.18 & 0.42 & 1.30 & 0.29 & 1.04 \\
\hline Mother's education missing & 0.08 & 0.26 & 0.09 & 0.28 & 0.06 & 0.24 \\
\hline Father self-employed in agriculture & 0.47 & 0.50 & 0.48 & 0.50 & 0.46 & 0.50 \\
\hline Father self-employed in non-agriculture & 0.16 & 0.37 & 0.15 & 0.35 & 0.18 & 0.38 \\
\hline Father wage-employed in non-labour & 0.10 & 0.30 & 0.11 & 0.31 & 0.10 & 0.30 \\
\hline Father wage-employed in (agricultural) labour & 0.20 & 0.40 & 0.19 & 0.39 & 0.22 & 0.41 \\
\hline Father unemployed & 0.05 & 0.21 & 0.06 & 0.23 & 0.03 & 0.18 \\
\hline Father in other jobs & 0.02 & 0.12 & 0.02 & 0.13 & 0.01 & 0.12 \\
\hline $\mathrm{N}$ & 5044 & & 2648 & & 2396 & \\
\hline
\end{tabular}

Note: The wealth index uses coefficients on household assets in a regression of household asset value (in logs) as weights. Alternative wealth indices are constructed using weights that are derived from household expenditure regressions. 
Table A3: Regression estimates of intergenerational correlation in wealth, inherited and split-off households [Dependent variable: son's wealth]

\begin{tabular}{|c|c|c|c|c|c|c|c|c|}
\hline & \multicolumn{4}{|c|}{ Inherited } & \multicolumn{4}{|c|}{ Split-offs } \\
\hline & OLS & OLS & IV & IV & OLS & OLS & IV & IV \\
\hline Father's wealth & $\begin{array}{c}0.549 \\
(37.99)^{* *}\end{array}$ & $\begin{array}{c}0.382 \\
(21.34)^{* *}\end{array}$ & $\begin{array}{c}0.643 \\
(8.06)^{* *}\end{array}$ & $\begin{array}{c}0.516 \\
(4.13)^{* *}\end{array}$ & $\begin{array}{c}0.507 \\
(31.98)^{* *}\end{array}$ & $\begin{array}{c}0.339 \\
(18.92)^{* *}\end{array}$ & $\begin{array}{c}0.368 \\
(4.11)^{* *}\end{array}$ & $\begin{array}{c}0.354 \\
(3.80)^{* *}\end{array}$ \\
\hline Schooling & & $\begin{array}{c}0.045 \\
(14.31)^{* *}\end{array}$ & $\begin{array}{c}0.025 \\
(3.83)^{* *}\end{array}$ & $\begin{array}{c}0.038 \\
(3.46)^{* *}\end{array}$ & & $\begin{array}{c}0.046 \\
(13.17)^{* *}\end{array}$ & $\begin{array}{c}0.044 \\
(6.56)^{* *}\end{array}$ & $\begin{array}{c}0.043 \\
(6.17)^{* *}\end{array}$ \\
\hline Household size & & $\begin{array}{c}0.046 \\
(10.28)^{* *}\end{array}$ & $\begin{array}{c}0.045 \\
(9.60)^{* *}\end{array}$ & $\begin{array}{l}-0.081 \\
(1.32)\end{array}$ & & $\begin{array}{c}0.036 \\
(4.86)^{* *}\end{array}$ & $\begin{array}{c}0.036 \\
(4.75)^{* *}\end{array}$ & $\begin{array}{l}-0.073 \\
(1.69)+\end{array}$ \\
\hline $\begin{array}{l}\text { Self-employed in } \\
\text { non-agriculture }\end{array}$ & & $\begin{array}{c}-0.095 \\
(3.61)^{* *}\end{array}$ & $\begin{array}{l}-0.056 \\
(1.87)+\end{array}$ & $\begin{array}{l}-0.106 \\
(2.37)^{*}\end{array}$ & & $\begin{array}{l}-0.016 \\
(0.56)\end{array}$ & $\begin{array}{l}-0.011 \\
(0.35)\end{array}$ & $\begin{array}{l}-0.008 \\
(0.24)\end{array}$ \\
\hline $\begin{array}{l}\text { Wage-employed in } \\
\text { non-agriculture }\end{array}$ & & $\begin{array}{c}-0.089 \\
(3.25)^{* *}\end{array}$ & $\begin{array}{l}-0.05 \\
(1.62)\end{array}$ & $\begin{array}{l}-0.111 \\
(2.27)^{*}\end{array}$ & & $\begin{array}{l}-0.064 \\
(2.23)^{*}\end{array}$ & $\begin{array}{l}-0.059 \\
(1.79)+\end{array}$ & $\begin{array}{l}-0.079 \\
(2.23)^{*}\end{array}$ \\
\hline $\begin{array}{l}\text { Wage-employed, } \\
\text { agricultural labour }\end{array}$ & & $\begin{array}{c}-0.287 \\
(6.51)^{* *}\end{array}$ & $\begin{array}{c}-0.245 \\
(5.19) * *\end{array}$ & $\begin{array}{c}-0.36 \\
(4.40)^{* *}\end{array}$ & & $\begin{array}{c}-0.142 \\
(3.63)^{* *}\end{array}$ & $\begin{array}{c}-0.137 \\
(3.28)^{* *}\end{array}$ & $\begin{array}{c}-0.179 \\
(3.85)^{* *}\end{array}$ \\
\hline OUemp & & $\begin{array}{c}-0.1 \\
(1.46)\end{array}$ & $\begin{array}{l}-0.071 \\
(1.00)\end{array}$ & $\begin{array}{l}-0.104 \\
(1.17)\end{array}$ & & $\begin{array}{l}-0.172 \\
(1.90)+\end{array}$ & $\begin{array}{l}-0.169 \\
(1.85)+\end{array}$ & $\begin{array}{c}-0.285 \\
(2.80)^{* *}\end{array}$ \\
\hline Constant & $\begin{array}{c}1.111 \\
(52.75)^{* *}\end{array}$ & $\begin{array}{c}1.284 \\
(8.12)^{* *} \\
\end{array}$ & $\begin{array}{c}1.10 \\
(6.15)^{* *}\end{array}$ & $\begin{array}{c}1.025 \\
(5.42)^{* *}\end{array}$ & $\begin{array}{c}0.963 \\
(49.12)^{* *} \\
\end{array}$ & $\begin{array}{c}0.661 \\
(3.24)^{* *}\end{array}$ & $\begin{array}{c}0.638 \\
(2.96)^{* *} \\
\end{array}$ & $\begin{array}{l}0.295 \\
(1.11) \\
\end{array}$ \\
\hline Adjusted $\mathrm{R}^{2}$ & 0.30 & 0.39 & - & - & 0.27 & 0.37 & - & - \\
\hline Over-identification test & - & - & 0.27 & 0.07 & - & - & 0.99 & 0.99 \\
\hline Exogeneity test & - & - & 0 & 0 & - & - & 0.74 & 0.02 \\
\hline $\mathrm{N}$ & 2648 & 2648 & 2648 & 2648 & 2396 & 2396 & 2396 & 2396 \\
\hline
\end{tabular}

Note: Excluded occupation dummy is self-employment in agriculture. All regressions control for individual's age, age-squared and religion. Instruments for father's wealth (in 1974) are father's occupation while instruments for son's family size are "treatment area dummy" and "sex of eldest child" (of the son). Robust standard errors are reported. Test of exogeneity (of father's wealth and son's household size) is based on Durbin-Wu-Hausman test with the null that the variable is exogenous. Over-identification test is based on Hansen's J-statistics. Only p-values are reported for the two tests. 
Table A4: Transition matrices of schooling, father-son pairs

\begin{tabular}{|c|c|c|c|c|c|c|c|}
\hline & & & & & Sons & & \\
\hline & & & $\begin{array}{l}\text { No } \\
\text { education }\end{array}$ & $\begin{array}{l}\text { Less than } \\
\text { primary }\end{array}$ & Primary & $\begin{array}{l}\text { Junior } \\
\text { secondary }\end{array}$ & $\begin{array}{r}\text { Secondary } \\
\text { or above }\end{array}$ \\
\hline & & & 1 & 2 & 3 & 4 & 5 \\
\hline & & 1 & 0.59 & 0.18 & 0.09 & 0.06 & 0.08 \\
\hline & Full sample & 2 & 0.36 & 0.22 & 0.14 & 0.11 & 0.18 \\
\hline & & 3 & 0.28 & 0.21 & 0.16 & 0.15 & 0.2 \\
\hline & & 4 & 0.15 & 0.18 & 0.19 & 0.14 & 0.34 \\
\hline & & 5 & 0.11 & 0.12 & 0.07 & 0.15 & 0.55 \\
\hline & Pearson's $\chi^{2}$ & & & & & & 842.63 \\
\hline & Likelihood $\chi^{2}$ & & & & & & 791.00 \\
\hline & & & 1 & 2 & 3 & 4 & 5 \\
\hline & & 1 & 0.56 & 0.19 & 0.09 & 0.07 & 0.09 \\
\hline Fathers & Inherited & 2 & 0.32 & 0.23 & 0.15 & 0.11 & 0.19 \\
\hline & households & 3 & 0.26 & 0.22 & 0.16 & 0.16 & 0.2 \\
\hline & & 4 & 0.13 & 0.17 & 0.19 & 0.17 & 0.35 \\
\hline & & 5 & 0.07 & 0.13 & 0.04 & 0.16 & 0.6 \\
\hline & Pearson's $\chi^{2}$ & & & & & & 514.98 \\
\hline & Likelihood $\chi^{2}$ & & & & & & 492.40 \\
\hline & & & 1 & 2 & 3 & 4 & 5 \\
\hline & & 1 & 0.61 & 0.17 & 0.09 & 0.06 & 0.07 \\
\hline & Split-offs & 2 & 0.41 & 0.22 & 0.11 & 0.1 & 0.16 \\
\hline & & 3 & 0.31 & 0.2 & 0.16 & 0.14 & 0.2 \\
\hline & & 4 & 0.18 & 0.21 & 0.19 & 0.1 & 0.31 \\
\hline & & 5 & 0.19 & 0.11 & 0.11 & 0.13 & 0.46 \\
\hline & Pearson's $\chi^{2}$ & & & & & & 308.58 \\
\hline & Likelihood $\chi^{2}$ & & & & & & 287.74 \\
\hline
\end{tabular}




\section{Appendix Note: Construction of the working sample}

\section{$\underline{\text { a. Source datasets }}$}

The data on 141 villages of the Matlab thana used in this study comes from the ICDDR,B which has maintained a demographic surveillance system (DSS) in the area since 1966. We use a random sample extracted from the database on the Matlab Socioeconomic Census (MSEC) 1996, a complete census of the study villages carried out by the ICDDR,B. The sample is drawn using the following rule. First, we selected a random sample of 2687 baris $^{21}$ from a total of 7440 baris in the Matlab thana. These 2687 baris are the same as those sampled for the Matlab Health and Socio-economic Survey (MHSS) 1996, an independent cross-section survey on the Matlab villages ${ }^{22}$. Then we extracted information on individuals residing in a total of 12015 maleheaded households in the sample baris.

The MSEC 1996 sample data does not automatically yield past records on parental characteristics (such as age and education) and outcomes (such as occupations and asset portfolio). Rather, it is available retrospectively from earlier rounds of the MSEC if parents co-resided with their adult children in the same household in the past. Using information on relationship to household-head in earlier census records, one can re-construct parental work history and other relevant characteristics. To this end, we bring in retrospective (socio-economic) information on parents and complete residential history data of current household-heads in the following manner. We extract retrospective records on all individuals who shared a household in 1982 and/or 1974 with our 1996 sample individuals ${ }^{23}$. This led to a total

\footnotetext{
${ }^{21}$ Baris usually consist of a cluster of households in close physical proximity linked in many instances in a kin-network.

${ }^{22}$ The MHSS 1996 chose bari as the primary sampling unit (PSU) rather than households and hence provided a better representation of family networks. Conditioning our sampling on the MHSS baris also allows us to link our data to the latter.

${ }^{23}$ The ICDDR,B collected census records for the entire Matlab population for the years 1974 and 1982.
} 
of 10430 male-headed households (out of in the MSEC 1996 sample for whom we had retrospective information implying an attrition rate of $13.2 \%$.

It should be noted, however, that the randomness of our working sample due to such attrition is not seriously comprised. The characteristics of the included and excluded ( $\mathrm{N}=1585)$ households (due to missing retrospective data) are strikingly similar $^{24}$. The few noticeable differences are: the heads of the excluded households are more educated, more often located in a single-household bari ${ }^{25}$ and have less cultivable land. However, an additional source of attrition prevails in the presence of non-random household division: more able/educated sons split and migrate outside the study area. Consequently, household residence (and/or residential cluster) based sampling akin to our sample may not yield unbiased estimates of economic mobility (Rosenzweig, 2003). One can only study mobility on the basis of past records of siblings who have continued to reside in the sample area for 22 years i.e. between 1974 and 1996. If so, this remains a limitation of our data.

For our empirical analysis, we construct two analytical samples, both consisting of male household heads ${ }^{26}$. The first sample consists of all heads (among the 10430 male heads in the MSEC 1996 sample) whose fathers were also present in the study area as a head in 1974. As such, we could obtain a random sample of fatherson pairs with complete information on them and their household characteristics permitting a study of intergenerational mobility. A total of 5113 sons are identified in the MSEC 1996 for whom their fathers were present as household heads in 1974. The remaining 5317 heads (in 1996) were discarded for any of the following four reasons: (1) the individual was also a head in $1974(\mathrm{~N}=4048)$; (2) the individual was not

\footnotetext{
${ }^{24}$ Results are available from the author upon request.

${ }^{25}$ The finding of residence in one-household bari is reassuring in the following sense. These (excluded) households are most likely to be recent migrants in the study area so that no information on their household of origin is available in the earlier MSEC records.

${ }^{26} \mathrm{We}$ focus on heads because data on assets is available only at the household level.
} 
present in the household in 1974 so that relation to head could not be ascertained $(\mathrm{N}=$ 263); (3) the individual lived in the study area in 1974 but his household was headed by his mother instead $(\mathrm{N}=165)$; and (4) the individual was present in a male-headed household in 1974 but not related to the head as a son $(\mathrm{N}=775)$. These conditions were imposed because records on parents were obtained by locating parents as heads in the earlier census rounds and subsequently, linking individuals/heads as father and son through relation of the individuals to the head of their households in 1996 and 1974. It should be noted that further attrition in the data due to application of these rules does not lead to a loss of randomness of our sample apart from the second rule. However, rule 2 leads to a negligible reduction in sample size (i.e. a total of 263 observations) and hence not a serious concern. There is a further but small loss of observations $(\mathrm{N}=69)$ due to missing data on wealth for some parents/sons altogether resulting in a sample of 5044 sons for whom we have complete contemporaneous data on their households and retrospective information on their parents and household of origin in childhood.

The second sample comprises of all adult sons in MSEC 1996 for whom repeated data is available. This sample includes 4048 heads in 1996 who also remained heads in earlier years (i.e. in 1974 and 1982). This sample permits an analysis of inter-temporal mobility.

\section{b. Identifying the split-offs}

It should be noted that information on whether a household headed by a son is a splitoff is not recorded in the data. It is nevertheless possible to decompose our main sample of household heads (5044 sons) on the basis of the history of their households' formation. To this end, we followed Foster (1993) and identified split-offs on the 
basis of changes in the relationship of individuals to the household-head over time. To be specific, we applied 3 rules following Foster (1993):

i. If the father is present as the head of another household in the study area in 1996, the son's household is a split-off.

ii. If the father is present as a non-head in a household in 1996, that household is inherited by the son who heads the household. Any remaining son observed to head a household where the father is not residing represents a split-off.

iii. If two or more siblings are present as heads in 1996 and the father is absent, the eldest brother has the inherited household and the younger brother heads a split-off.

Application of these rules led to a total of 2425 (47\%) split-offs against 2688 (53\%) inherited households ${ }^{27}$. Given that we treat bari as the PSU in this study, our sample provides a better representation of the split-offs. This is because, anecdotal evidence suggests that sons who do not migrate outside their village of origin in most cases set up households in close proximity to father's household and hence located in the same bari.

\section{c. Creating a wealth index}

Matlab censuses neither contained data on value of the household assets nor was any information available on the stocks of assets reportedly owned by a household. Information on sources of drinking water, quality of housing and various consumer durables nevertheless exist. Therefore, we constructed an aggregate measure of household wealth by combining data on household assets, quality of dwelling, usage and sources of water. The main challenge in creating such an index is the choice of appropriate weights. Our preferred method of aggregation is one where weights for

\footnotetext{
${ }^{27}$ This is comparable with Rosenzweig (2003) who, using Bangladeshi panel data, find that the rate of household division is $48 \%$ over a period of 18 years.
} 
each item entering the household wealth index are derived from an underlying regression that explicitly links total value of household wealth to various assets (see Table A1). To be precise, using data on the linked MSEC-MHSS sample households, we regress total $(\log )$ value of household assets on the 12 variables additionally controlling for household size, schooling of head, and his spouse ${ }^{28}$. Data on asset value are obtained from the MHSS 1996. (Detailed regression results available from the authors upon request). The OLS coefficients on the 12 variables are stored and applied respectively as weights to aggregate the indicator variables into a scalar quantity, subsequently for various rounds of the MSEC data.

\footnotetext{
${ }^{28}$ Total value of household assets comprised of current value of the followings items: homestead land, ornaments, savings, television, radio, clock, fan, bicycle, furniture and quilt.
} 